\title{
Resilience of Social-ecological Systems to Human Perturbation: Assessing Dongting Lake in China
}

\author{
$\mathrm{Li} \mathrm{Xu}^{1}$, Dora Marinova ${ }^{1} \&$ Xiumei Guo ${ }^{1}$ \\ ${ }^{1}$ Curtin University Sustainability Policy (CUSP) Institute, Curtin University, Perth, Australia \\ Correspondence: Dora Marinova, Curtin University Sustainability Policy (CUSP) Institute, Curtin University, \\ GPO Box U1987, Perth WA 6845, Australia. Tel: 61-8-926-690-331. E-mail: D.Marinova@curtin.edu.au
}

\author{
Received: July 22, 2015 Accepted: August 17, 2015 Online Published: September 27, 2015 \\ doi:10.5539/jsd.v8n8p182 URL: http://dx.doi.org/10.5539/jsd.v8n8p182
}

\begin{abstract}
This paper conducts an assessment on the social-ecological resilience of China's Dongting Lake (and its three sections - East, West and South Dongting Lake) in relation to the perturbations of the Three Gorges Dam using a set of resilience-based indicators. Expert scoring is applied to identify the different states of the lake and their resilience levels. Based on equal weighting for all indicators and using the technique of ordering preferences according to similarity to the ideal solution, an assessment of the social-ecological resilience of Dongting Lake is generated. The results show that East Dongting has higher ability to absorb perturbations than South and West Dongting which have relatively low resilience to the changes triggered by the impoundment of the Dam. Effective adaptation measures are needed for the lake to be able to better absorb these perturbations and be sustainable in the long run.
\end{abstract}

Keywords: resilience indicators, social-ecological systems, sustainability, Three Gorges Dam

\section{Introduction}

Human perturbations worldwide are increasingly driving changes in freshwater ecosystems (Gleick et al., 2014). Disturbances from people and their activities have triggered numerous problems with contradictory and difficult to resolve requirements creating increasing challenges related to deteriorating environmental conditions of freshwater systems, water scarcity and safety. An example of this is climate change with its global impacts but there are also many local cases related directly to water use, such as the building of barrages, weirs and dams which change the hydrology of the region.

Accessing reliable water resources is a most important population need. The main storage of water for human use is lakes and they represent $70 \%$ of the global surface freshwater (Jorgensen, 2008). An estimated $68 \%$ of the world's liquid surface freshwater is contained in 189 large lakes (Reid \& Beeton, 1992). They provide many important social and ecological services, such as water for drinking, irrigation and industry, habitat for various living species and place for dilution of pollutants. The interconnectedness and interdependent relationships between humans and nature are described through the concept of social-ecological systems (Berkes \& Folke, 1998). People however often impact on the state of nature, including impairing the services of the lakes and placing many of them in peril through unsustainable exploitation for industrial development and urbanisation (Carpenter \& Cottingham, 1997). Increasing demand for water, high pollution levels and the declining health of the freshwater ecosystems are continuously threating the availability of freshwater (Biswas, 1991; Johnson Revenga, \& Echeverria, 2001).

Hydropower projects, involving the construction of big dams and their use for electricity generation, agricultural irrigation and provision of drinking water, are delivering economic benefits but also changing the hydrological conditions of the areas. China is continuously supporting such water-related projects with investment increasing from $¥ 94.49$ billion in 2007 to $¥ 375.76$ billion in 2013 (Ministry of Water Resources of China, 2014). The ecological impacts of these large dams are drawing significant attention due to the implications they have for the state of the watersheds (Kingsford, 2000; Lajoie, Assani, Roy, \& Mesfioui, 2007; Tullos, 2009; P. Wang, Lassoie, Dong, \& Morreale, 2013). When the impoundment is upstream from a lake, the disturbances alter the hydrological conditions of the watershed and also have potential impact on the health of the joint social-ecological systems (SESs) (Xu, Marinova, Xin, \& Guo, 2015a). The new hydrological conditions during the period of the dam's operation may cause a regime shift for the lake. Dongting Lake and Poyang Lake - the 
two lakes connected to China's Yangtze River (YR), are subjected to the impacts of the Three Gorges Dam (Liu, $\mathrm{Wu}, \&$ Zhao, 2013). In order to respond to the growing changes caused by the perturbations from the dam, understanding the lakes' resilience is becoming an urgent task.

Resilience is the capacity of a system to tolerate disturbances without collapsing into another domain in which its state is qualitatively different (Walker et al., 2006). Instead of trying to control change, a resilience view of the world shifts our thinking to dealing with and adapting to it (Berkes, 2007). From a sustainability point of view, resilience does not call for finding the optimal pathway for the future but implies thinking about how to steer the SESs towards trajectories which avoid undesirable positions or states (Walker, 2014). It is therefore important to understand what the desirable states are, what changes may happen that result in undesirable states, and how to determine and cope with the uncertainties that may cause these changes.

In recent years, resilience research is experiencing a period of boom during which its coverage was extended from ecological systems (as first introduced by Holling in 1973) to SESs (Xu \& Marinova, 2013; Leitch \& Bohensky, 2014). This includes research focussed on aquatic systems, coral reefs, agriculture, cities and catchment management (Carpenter, Ludwig, \& Brock, 1999; Nystrom, Folke, \& Mogerg, 2000; Cabell \& Oelofse, 2012; Newman, Beatley, \& Boyer, 2009; Walker, Abel, Anderies, \& Ryan, 2009). Assessing resilience, especially for SESs, however still remains problematic because of the complexity and paucity of relevant data (Xu, Marinova, \& Guo, 2015b).

This study is the first attempting to assess the social-ecological resilience of Dongting Lake under the impacts of the Three Gorges Dam (TGD). It aims to analyse the health of the SESs of this freshwater lake under the impact of this serious disturbance. With not all necessary data available, expert scoring is used as a proxy in this assessment. Yet, the analysis allows for a reliable picture of the lake's situation to be presented. After explaining the methodology of the study (see Section 2), an assessment of Dongting Lake is conducted (see Section 3) and the results are discussed (see Section 4). The conclusion argues the need for policy responses and further research on the resilience of freshwater lakes.

\section{Methods and material}

\subsection{Study Site}

Dongting Lake, with a drainage area of $262800 \mathrm{~km}^{2}$, is the second largest freshwater lake in China (Feng, Hu, Chen, \& Zhao, 2013). Administratively located in Hunan Province, it is conjunct to the YR in its middle stream and is a seasonal and shallow lake consisting of three parts: East Dongting (ED), South Dongting (SD) and West Dongting (WD). The water from the YR comes to the lake through three inlets - Songzi, Taiping and Ouchi, in northwest and goes out to the same river through the Chenglingji outlet in northeast. Four joint local rivers (Xiang, $\mathrm{Zi}$, Yuan and $\mathrm{Li}$ ) also supply water to the lake from the south. The annual water inflow is about 312.6 billion $\mathrm{m}^{3}, 38 \%$ of which comes from the YR (Y. Li, 2014). In the wet season (June to September), the maximum water surface area can reach up to $2691.2 \mathrm{~km}^{2}$ while it shrinks to about $500 \mathrm{~km}^{2}$ in the dry season (Lai, Jiang, \& Huang, 2013; Y. Li, 2014). The spatial boundary of this case study is defined as the three parts of the lake (ED, SD and WD) together with the main counties and districts in the three cities along the lake, namely Junshan district, Yueyang county and Miluo city in the ED area, Xiangyin county and Yuanjiang city in the SD area, Hanshou county, Anxiang county and Nanxian county in the WD area (see Figure 1).

\subsection{Methods}

A range of indicators was developed by $\mathrm{Xu}$ et al. (2015a) for resilience assessment of freshwater lakes and the specific area of Dongting Lake. These indicators (see Table 1 and 2) describe the resilience of the freshwater lakes' SESs to external perturbations, including both their self-organising capacities and policy responses (see Figure 2), as they relate to the specific components of the systems or subsystems. The Dongting Lake's subsystems cover resources - water, wetlands, fish, water birds, productivity for human use and predictability; resource units - the actual quantities, distributions, growth rates and mobility; governance systems - ecological, economic and social policies, NGOs, property rights and local observation; and human users - number of people, their knowledge, leadership, common values and economic or cultural dependence on the lake (refer also to Table 1). Each subsystem is described by second layer subsystems and variables for which specific indicators are required in order to understand the resilience of the SES of the Dongting Lake. These indicators are explained below followed by description of the expert participation and assessment criteria used for the evaluation.

\subsubsection{Indicators and Calculation}

A detailed description of the resilience indicators together with the respective calculation methods based on data availability is presented in Table 2 and 3 . When possible, a quantitative calculation is used for system capacity 
indicators (see Table 2) which can be measured or for which statistical data are available. If this is not the case, surrogates are used or expert scoring is applied with "1", "2", "3" and "4" indicating respectively "not resilient", "low resilience", "medium resilience" and "high resilience".

The indicators related to policy responses (see Table 3) are assessed based on document analysis whether they are (or not) available to use for adapting to the systems' changes. Scores are given to each response based on the status in the policy-making process, namely "1", "2", "3" and "4" to indicate respectively "unavailable", "in progress", "being implemented" and "works effectively" representing different levels of resilience - "not resilient", "low resilience", "medium resilience" and "high resilience" (see Table 3). For example, if policy $P_{l}$ is at the stage of being debated (in progress) either in academia or government, its score is valued at " 2 ".

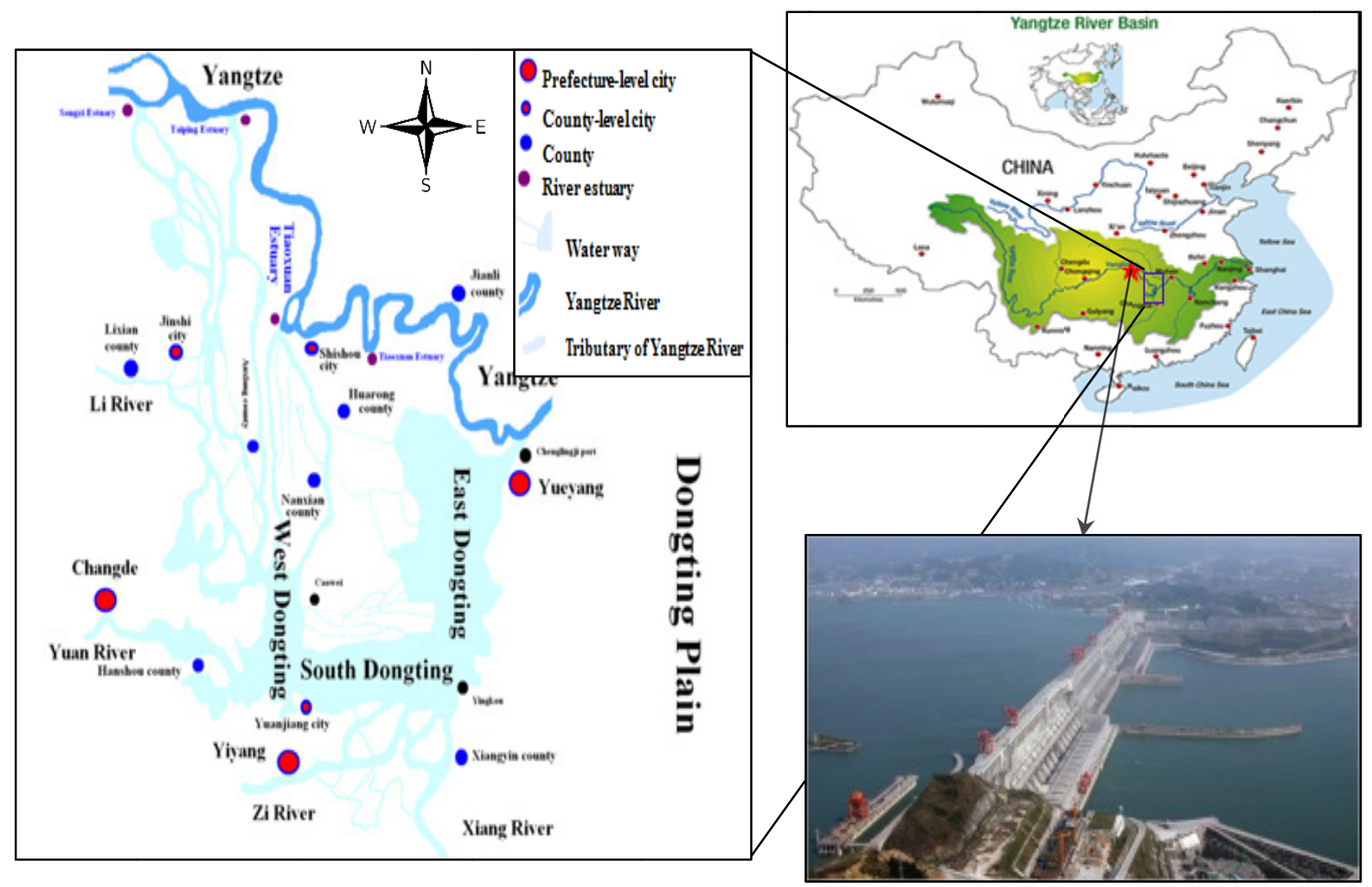

Figure 1. Location of Dongting Lake and the Three Gorges Dam

Table 1. Core subsystems and multiple variables of SESs of Dongting Lake

\begin{tabular}{|c|c|c|c|}
\hline $\begin{array}{l}\text { First layer } \\
\text { subsystems }\end{array}$ & Second layer subsystems and variables & $\begin{array}{l}\text { First layer } \\
\text { subsystems }\end{array}$ & Second layer subsystems and variables \\
\hline \multirow{6}{*}{$\begin{array}{c}\text { RS - Resource } \\
\text { Systems }\end{array}$} & RS 1.1-Water & \multirow{6}{*}{$\begin{array}{c}\mathbf{R U}-\text { Resource } \\
\text { Units }\end{array}$} & RU 1 - Resource unit mobility \\
\hline & RS 1.2 - Wetlands & & RU 2 - Growth and replacement rate \\
\hline & RS 1.3 - Fish & & RU 3 - Economic value \\
\hline & RS 1.4 - Water birds & & RU 4 - Quantity of units \\
\hline & RS 4 - Productivity of system & & RU 5.1 - Non-homogeneous distribution of units \\
\hline & RS 5 - Predictability of system dynamics & & RU 5.2 - Homogeneous distribution of units \\
\hline \multirow{7}{*}{$\begin{array}{c}\text { GS - } \\
\text { Governance } \\
\text { Systems }\end{array}$} & GS 1.1 - Ecological policy & \multirow{7}{*}{$\mathbf{U}$-Users } & U 1 - Number of users \\
\hline & GS 1.2 - Economic-ecological policy & & U 5 - Leadership \\
\hline & GS 1.3 - Social-ecological policy & & U 6.2 - Common interest/shared norms \\
\hline & GS $2.2-$ NGOs & & U 7 - Knowledge of SES \\
\hline & GS 3.1 - Property rights & & U 8.1 - Economic dependence \\
\hline & GS 3.2 - Collective-choice rules & & \multirow{2}{*}{ U 8.2 - Cultural dependence } \\
\hline & GS 6.1 - Local observation & & \\
\hline
\end{tabular}

Source: Compiled from Xu et al. (2015a) 

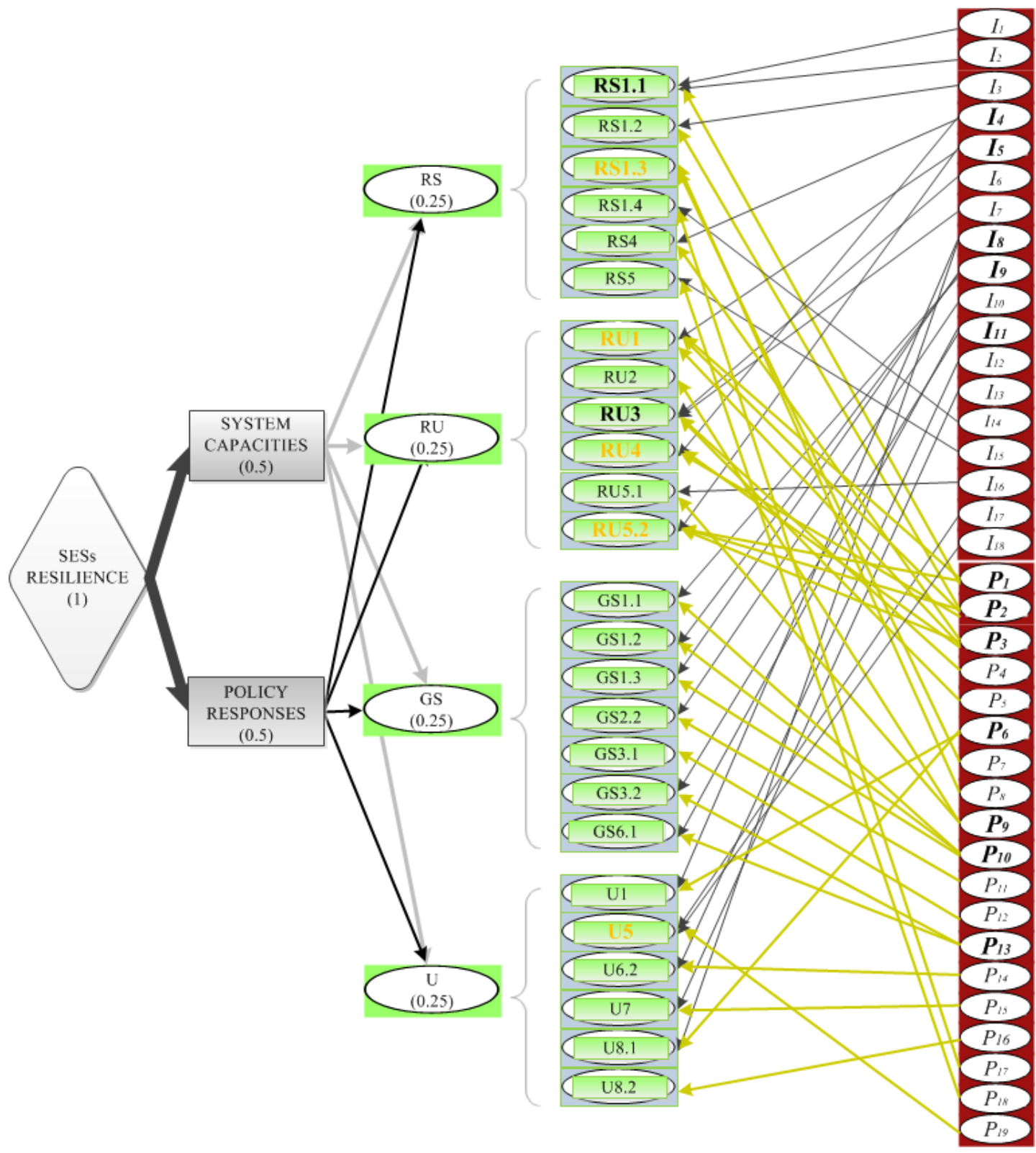

Figure 2. Hierarchical networks between SESs and indicators

Table 2. Indicators for system abilities and calculation

\begin{tabular}{|c|c|c|c|c|}
\hline Indicator & Calculation/surrogate & Direction & Interpretation & Data source \\
\hline Water storage $\left(I_{I}\right)$ & Water level & Positive & $\begin{array}{l}\text { Due to multifaceted factors, including } \\
\text { geomorphology, water level is usually used to } \\
\text { estimate the water storage of lakes }\end{array}$ & Li (2014) \\
\hline $\begin{array}{l}\text { Water } \\
\text { supply-demand ratio } \\
\left(I_{2}\right)\end{array}$ & $R_{w}=\mathrm{Q} /\left(\mathrm{Dz}_{1}+\mathrm{Dz}_{2}\right)$ & Positive & $\begin{array}{l}\mathrm{Q} \text { is water supply of the lake; } \mathrm{D}_{\mathrm{z}}-\text { water demands } \\
\text { of the lake's region; } \mathrm{z}_{1} \text { and } \mathrm{z}_{2}-\text { ecological and } \\
\text { socioeconomic demand }\end{array}$ & $\begin{array}{l}\text { Tong, Han, Lei, \& Li } \\
\text { (2014); Hunan Water } \\
\text { Resource Bulletin }\end{array}$ \\
\hline $\begin{array}{l}\text { Coverage of } \\
\text { emergent } \\
\text { macrophytes }\left(I_{3}\right)\end{array}$ & Questionnaire & Positive & $\begin{array}{l}\text { The core species indicating this is Carex brevicuspis } \\
\text { - the main food source for waterbirds. Data are not } \\
\text { available }\end{array}$ & Expert scoring \\
\hline
\end{tabular}


Regeneration rate of resources $\left(I_{4}\right)$

Questionnaire

Positive

Liveable space for key species $\left(I_{5}\right)$

Questionnaire

Positive

Households'

financial wealth $\left(I_{6}\right)$

Urban-rural poverty gap

Negative

Number of production methods (level of

Questionnaire

Positive

productivity) $\left(I_{7}\right)$

\section{Education}

attainment $\left(I_{8}\right)$

Dominant education level in the region

Degree of public participation in policy making $\left(I_{9}\right)$

Diversity of stakeholder networks in the region $\left(I_{10}\right)$

Composition of stakeholders involved $\left(I_{11}\right)$

Size of local common interest groups $\left(I_{12}\right)$

Population's illiteracy rate $\left(I_{13}\right)$

Illiteracy rate

Change of habitat of water birds $\left(I_{14}\right)$

Questionnaire

Negative

Share of locals concerned about environmental changes $\left(I_{15}\right)$

Change in spatial patterns $\left(I_{16}\right)$

Field surveys

Negative

Media coverage for social groups $\left(I_{17}\right)$

Online statistics

Positive

Social influence power $\left(I_{18}\right)$
The regeneration rate can be estimated in comparison with the rate of loss

Data about liveable space for the key species, especially fish, are fragmented

Most people around the lake live in rural areas. The urban-rural gap (urban residents' disposable income/rural residents' annual net income per capita) can be used to estimate the households' financial ability to deal with problems. The smaller the gap is (i.e. the higher the value), the wealthier they are.

The more production methods people residing in the lake areas have, the higher their resilience when resources are short

Education attainment can indicate the quality of labour skills. The higher educated people of the region are, the higher their level of resilience

The extent to which the public is satisfied with participation in policy-making is used to estimate the degree of its participation

Networks can include public activities and research collaborations

Stakeholder participation should be representative and equal rules should applied to everyone

As there are no authorised local common interest groups in the regions, NGOs are used as surrogate

Illiteracy rate is an important demographic variable. A lower illiteracy rate means the residents of the region have higher ability to learn knowledge

Habitat change is an early warning signal to determine the effect of perturbation on waterbirds. The smaller the changes the less likely are they to affect the waterbirds

Complaint reports indicate the degree of people's concern about their environmental situations

This indicates whether the non-homogeneous distribution of units in the SESs of the regions has changed; due to data limitation, spatial patterns assessed by experts can be used as an early warning

Environmental NGOs in the three regions are used as representative. Data in obtained with online search engines

Influence power of leading social groups can indicate their ability to contribute
Expert scoring

Interviews and expert scoring

Yearbook of Hunan

Province

\section{Expert scoring}

Sixth Nationwide Population Census Bulletin: Hunan

Interviews and expert scoring

Sixth Nationwide Population Census Bulletin: Hunan

Expert scoring

Environmental Protection Department of Hunan

Expert scoring

News reports

Expert scoring 
Table 3. Indicators for policy responses

\begin{tabular}{|c|c|c|c|}
\hline Indicator & $\begin{array}{l}\text { Resilience } \\
\text { description }\end{array}$ & $\begin{array}{l}\text { Resilience } \\
\text { state }\end{array}$ & Description \\
\hline $\begin{array}{l}\text { Water quantity } \\
\text { adjustment plans }\left(P_{1}\right)\end{array}$ & In progress & $\begin{array}{l}\text { Low } \\
\text { resilience }\end{array}$ & $\begin{array}{l}\text { There are discussions about three groups of options (water transferred from } \\
\text { YR, building of new gates and improving the regulations for TGD) }\end{array}$ \\
\hline restoration & $\begin{array}{l}\text { Being } \\
\text { implemented }\end{array}$ & $\begin{array}{l}\text { Medium } \\
\text { resilience }\end{array}$ & $\begin{array}{l}\text { Desilting of the lake, farmland reclamation around the lake, habitat restoration } \\
\text { programs (started before the operation of the Dam but adaptations for its } \\
\text { disturbance are needed) }\end{array}$ \\
\hline $\begin{array}{l}\text { Protection plans for the } \\
\text { resources in the lake }\left(P_{3}\right)\end{array}$ & $\begin{array}{l}\text { Works } \\
\text { effectively }\end{array}$ & $\begin{array}{l}\text { High } \\
\text { resilience }\end{array}$ & $\begin{array}{l}\text { Yearly events: International Festival of Birds Observation (since 2002), Love } \\
\text { Birds Week (since 1981); spring ban for fishing; national and provincial } \\
\text { protection regulations (12th Five-year Plan for local wetlands and natural } \\
\text { resources protection, 2010); ban on ways of illegal fishing (such as } \\
\text { "Mi-hun-zhen") harmful for the sustainability of fish resources; closed, } \\
\text { seasonal and periodical management of reserved areas }\end{array}$ \\
\hline Financial support $\left(P_{4}\right)$ & $\begin{array}{l}\text { Being } \\
\text { implemented }\end{array}$ & $\begin{array}{l}\text { Medium } \\
\text { resilience }\end{array}$ & $\begin{array}{l}\text { Investment in irrigation infrastructures; national financial support programs } \\
\text { approved; WWF programs for the protection of the lake (2006) }\end{array}$ \\
\hline $\begin{array}{l}\text { Technological support } \\
\text { plans }\left(P_{5}\right)\end{array}$ & $\begin{array}{l}\text { Being } \\
\text { implemented }\end{array}$ & $\begin{array}{l}\text { Medium } \\
\text { resilience }\end{array}$ & $\begin{array}{l}\text { Organic fishery program; farmland irrigation infrastructures and ecological } \\
\text { agriculture programs }\end{array}$ \\
\hline $\begin{array}{l}\text { Programs to help locals } \\
\text { with economic income } \\
\left(P_{6}\right)\end{array}$ & $\begin{array}{l}\text { Being } \\
\text { implemented }\end{array}$ & $\begin{array}{l}\text { Medium } \\
\text { resilience }\end{array}$ & $\begin{array}{l}\text { Development of ecological tourism, agriculture and fishery; Dongting Lake } \\
\text { Ecological Economic Zone program (in progress) }\end{array}$ \\
\hline $\begin{array}{l}\text { Reproduction and } \\
\text { protection plans for fish's } \\
\text { living space }\left(P_{7}\right)\end{array}$ & In progress & $\begin{array}{l}\text { Low } \\
\text { resilience }\end{array}$ & $\begin{array}{l}\text { Representative areas of integrated utilities for agriculture, livestock and } \\
\text { fishery around the lake; putting young fish into the lake every year (started } \\
\text { long ago but the effects are small) }\end{array}$ \\
\hline $\begin{array}{l}\text { Food chain protection } \\
\left(P_{8}\right)\end{array}$ & In progress & $\begin{array}{l}\text { Low } \\
\text { resilience }\end{array}$ & $\begin{array}{l}\text { No specific protections for food chains in the lake, restoring habitats and } \\
\text { water adjustment will be helpful for the integrity of food chains in the lake. }\end{array}$ \\
\hline $\begin{array}{l}\text { Long-term monitoring } \\
\text { plans and experimental } \\
\text { programs for key species } \\
\left(P_{9}\right)\end{array}$ & $\begin{array}{c}\text { Being } \\
\text { implemented }\end{array}$ & $\begin{array}{l}\text { Medium } \\
\text { resilience }\end{array}$ & $\begin{array}{l}\text { Several monitor stations covering } \mathrm{ED}, \mathrm{SD} \text { and WD areas for waterbirds, } \\
\text { wetlands, water quality and other variables relating to the state of the lake; a } \\
\text { database developed for WD; barriers exist - lack of professional staff and } \\
\text { advanced instruments }\end{array}$ \\
\hline
\end{tabular}

Diversity of policy responses for the long-term $\left(P_{10}\right)$

Diversity of policy support to local NGOs $\left(P_{11}\right)$

Compensations for loss of access to the lake's resources $\left(P_{12}\right)$

Complementary policies for enhancing collective action among stakeholders $\left(P_{13}\right)$

Strategies to encourage social groups $\left(P_{14}\right)$

Unavailable

Not resilient

Policies for many aspects of the lake's health, but no policies specifically for disturbance by TGD

In progress

Low resilience

Limited support from the government for local environmental NGOs; the biggest barrier for the NGOs is the lack of financial support

\section{Being Medium} implemented resilience

\section{Being} implemented

In progress

Works effectively
Long-term strategies for education about the dynamics of SESs $\left(P_{15}\right)$
Financial compensation available for fishers for income reduction during periods of ban on fishing in spring months (since 2008)

Established collaboration with universities, institutes and governmental authorities; locals encouraged to get involved in co-management practices for the lake's health (Beijing Forest University, Chinese Academy of Sciences, Hunan Normal University; community co-management practice in Qingshanyuan) (since 2005).

Low Basic encouragement, mainly with co-organizing communities events; still resilience insufficient financial support for wider NGOs activities.

Many education strategies adopted in the areas along the lake - advertising, High TV programs, brochures, permanent warning signs, periodic exhibitions resilience (videos and photographs) about environmental protection and education centres. 


\begin{tabular}{|c|c|c|c|}
\hline $\begin{array}{l}\text { Strategies maintaining } \\
\text { traditional culture }\left(P_{16}\right)\end{array}$ & Unavailable & $\begin{array}{l}\text { Not } \\
\text { resilient }\end{array}$ & $\begin{array}{l}\text { Cultural dependence in the areas based on agriculture and fishery; strategies } \\
\text { put in place to encourage ecologically sound production; no strategies to keep } \\
\text { their traditional cultures. }\end{array}$ \\
\hline $\begin{array}{l}\text { Long-term observation of } \\
\text { distribution and quantity } \\
\text { of water birds }\left(P_{17}\right)\end{array}$ & $\begin{array}{l}\text { Being } \\
\text { implemented }\end{array}$ & $\begin{array}{l}\text { Medium } \\
\text { resilience }\end{array}$ & $\begin{array}{l}\text { Several monitoring stations established covering ED, SD and WD areas; } \\
\text { annual International Festival of Birds Observation and collaboration research } \\
\text { groups help with observing birds. }\end{array}$ \\
\hline $\begin{array}{l}\text { Long-term monitoring of } \\
\text { key variables }\left(P_{18}\right)\end{array}$ & $\begin{array}{l}\text { Being } \\
\text { implemented }\end{array}$ & $\begin{array}{l}\text { Medium } \\
\text { resilience }\end{array}$ & $\begin{array}{l}\text { The established monitoring stations cover a large part of the lake and many } \\
\text { aspects of its state; a long time required to see the effects. }\end{array}$ \\
\hline $\begin{array}{l}\text { Social rights regulations } \\
\left(P_{19}\right)\end{array}$ & Unavailable & $\begin{array}{l}\text { Not } \\
\text { resilient }\end{array}$ & $\begin{array}{l}\text { No governmental regulations dealing specifically with the rights of social } \\
\text { groups and environmental NGOs in protection activities. }\end{array}$ \\
\hline
\end{tabular}

\subsubsection{Expert Participation}

Identifying thresholds of SESs is difficult, particularly when there is no evidence whether they or alternative regimes of the system exist. Expert assessment can help describe possible regimes and the scales of different resilience levels of the system. The experts identify the levels of resilience of the lake's SESs and also score the indicators for which data are not available.

Twenty experts familiar with the ecological and socioeconomic systems of the Dongting Lake region were involved in this study. Their opinion was collected using questionnaires consisting of 24 questions and a scoring table. The first part containing multiple-choice questions solicited knowledge about possible regimes of the SESs and thresholds; the second part was a table where experts were asked to assign scores to indicators. Half of the experts were participants in the December 2014 annual meeting of the Chinese "973" project on the interaction between the TGD and the river-connected lakes. The others were experts from the Dongting Lake Station for Wetland Ecosystem Research of the Chinese Academy of Sciences which has a specific focus on the ecological systems of the region.

\subsubsection{States and Assessment Criteria}

A threshold describes the maximum or minimum limit for a system to stay in a relatively stable state, and crossing it, even with a small change, can cause critical transitions to occur. For the purpose of assessment, a threshold not only indicates when or where the regime shifts happen but also defines the upper and lower bounds for standard criteria. From a sustainability point, it is important to keep systems in the desired configuration of states for all critical variables rather than maximise any specific supply of goods or services.

The possible regimes of freshwater lakes are identified as clean or turbid determined by the phosphate concentration in the catchment soils and lake sediments (Carpenter et al., 1999; Scheffer, Brock, \& Westley, 2000; Falk et al., 2004). The regimes of the lakes' SESs are further influenced by changes in the hydrological conditions which play an important role for the state of the freshwater lakes' ecosystems in terms of water quantity. This is even more the case with the increasing impacts of climate change and big dam impoundment (Zhao, Cong, Barter, Fox, \& Cao, 2012). For example, the quantity of water in a lake is essential for the living biota of the region by providing habitat and is also critical for regional security in terms of flood control and drought alleviation. Questions which require consideration are: Would hydrological changes cause regime shifts for the freshwater lakes that are different from either turbid or clean? How far is the system from unsustainable thresholds? These are discussed in relation to the situations in which the system can or cannot absorb the occurring changes (see Table 4). Thresholds are normally identified by evidence-based methods and manifested alternate regimes can be found from the literature or news reports. If this is not possible, expert assessment or proxies are used to estimate where such thresholds could be.

Table 4. Indicator scales for different levels of resilience of SESs

\begin{tabular}{|c|c|c|c|c|c|c|}
\hline \multirow{2}{*}{ Indicator } & \multicolumn{2}{|c|}{ Regimes/configurations } & \multicolumn{4}{|c|}{ Scales of different status of resilience and descriptions } \\
\hline & desirable & undesirable & non-resilient & low resilience & medium resilience & high resilience \\
\hline $\begin{array}{c}I_{1} \\
\text { Note } 1\end{array}$ & $\begin{array}{l}\text { Enough for use } \\
\text { in (1) dry and } \\
\text { (2) wet seasons }\end{array}$ & Extreme drought & $\begin{array}{l}\text { (1) } I_{1}<23 \mathrm{~m} \text { or } \\
I_{1}>32 \mathrm{~m} \\
\text { (2) } I_{1}<29.5 \mathrm{~m} \text { or } \\
I_{1}>34 \mathrm{~m}\end{array}$ & $\begin{array}{c}\text { (1) } 23 \mathrm{~m} \leq I_{l}<26 \mathrm{~m} \\
\text { (2) } 29.5 \mathrm{~m} \leq I_{l}< \\
31 \mathrm{~m}\end{array}$ & $\begin{array}{l}\text { (1) } 26 \mathrm{~m} \leq I_{1}<29 \mathrm{~m} \\
\text { (2) } 31 \mathrm{~m} \leq I_{1}<32.5 \mathrm{~m}\end{array}$ & $\begin{array}{c}\text { (1) } 29 \mathrm{~m} \leq I_{I} \leq 32 \mathrm{~m} \\
\text { (2) } 32.5 \mathrm{~m} \leq I_{I} \leq \\
34 \mathrm{~m}\end{array}$ \\
\hline
\end{tabular}




\begin{tabular}{|c|c|c|c|c|c|c|}
\hline$I_{2}$ & $\begin{array}{l}\text { Meet average } \\
\text { demands of } \\
\text { SESs }\end{array}$ & A large gap exists & $\begin{array}{c}\text { Basic ecological } \\
\text { demands cannot } \\
\text { be meet }\end{array}$ & $\begin{array}{c}R_{w}<0.5, \text { water } \\
\text { satisfies basic } \\
\text { ecological } \\
\text { demands }\end{array}$ & $\begin{array}{c}\quad 0.5 \leq R_{w}<1, \\
\text { basic demands of } \\
\text { SESs can be met }\end{array}$ & $\begin{array}{c}\quad R_{w}=1, \\
\text { SESs' demands } \\
\text { can be fulfilled }\end{array}$ \\
\hline $\begin{array}{c}I_{3} \\
\text { Note } 2\end{array}$ & $\begin{array}{c}\text { Species do not } \\
\text { lose their } \\
\text { habitat }\end{array}$ & $\begin{array}{l}\text { Extinction of species caused by } \\
\text { isolation and fragmentation }\end{array}$ & $\begin{array}{l}\text { Habitat cannot } \\
\text { support most } \\
\text { water birds }\end{array}$ & $\begin{array}{l}\text { Habitat cannot } \\
\text { support more than } \\
50 \% \text { of water } \\
\text { birds }\end{array}$ & $\begin{array}{c}\text { Habitat is } \\
\text { fragmental but can } \\
\text { support } 50-80 \% \text { of } \\
\text { water birds }\end{array}$ & $\begin{array}{l}\text { Habitat is } \\
\text { integrated and can } \\
\text { support more than } \\
80 \% \text { of water birds }\end{array}$ \\
\hline $\begin{array}{c}I_{4} \\
\text { Note } 3\end{array}$ & $\begin{array}{l}\text { Above the rate } \\
\text { of loss }\end{array}$ & Under the rate of loss & $\begin{array}{l}\text { Loss/regeneration } \\
\text { (ratio) is higher } \\
\text { than } 0.7\end{array}$ & $\begin{array}{c}\text { Loss/regeneration } \\
\text { (ratio) is between } \\
0.4 \text { and } 0.7\end{array}$ & $\begin{array}{c}\text { Loss/regeneration } \\
\text { (ratio) is between } \\
0.1 \text { and } 0.3\end{array}$ & $\begin{array}{l}\text { Lost/regeneration } \\
\text { (ratio) is lower } \\
\text { than } 0.1\end{array}$ \\
\hline$I_{5}$ & $\begin{array}{l}\text { Enough living } \\
\text { space for key } \\
\text { species }\end{array}$ & $\begin{array}{l}\text { Not enough living space for key } \\
\text { species }\end{array}$ & $\begin{array}{l}\text { Cannot be } \\
\text { restored }\end{array}$ & $\begin{array}{l}\text { Reduced and very } \\
\text { hard to restore }\end{array}$ & $\begin{array}{l}\text { Reduced but parts } \\
\text { can be restored }\end{array}$ & $\begin{array}{l}\text { Reduced but easy } \\
\text { to restore }\end{array}$ \\
\hline $\begin{array}{c}I_{6} \\
\text { Note } 4\end{array}$ & $\begin{array}{l}\text { Urban/rural gap } \\
\text { is acceptable }\end{array}$ & $\begin{array}{c}\text { Urban/rural gap can cause social } \\
\text { crisis }\end{array}$ & $\begin{array}{c}\text { The gap is larger } \\
\text { than } 3\end{array}$ & $\begin{array}{l}\text { The gap is } \\
\text { between } 2.5 \text { and } 3\end{array}$ & $\begin{array}{c}\text { The gap is between } \\
2 \text { and } 2.4\end{array}$ & $\begin{array}{c}\text { The gap is between } \\
1.5 \text { and } 1.9\end{array}$ \\
\hline$I_{7}$ & $\begin{array}{l}\text { Multiple } \\
\text { technological } \\
\text { production } \\
\text { methods } \\
\text { available }\end{array}$ & $\begin{array}{l}\text { Very few production methods } \\
\text { available }\end{array}$ & $\begin{array}{c}\text { Production stops } \\
\text { when resources } \\
\text { are short }\end{array}$ & $\begin{array}{l}\text { Lag in response } \\
\text { with technology } \\
\text { to resource } \\
\text { availability }\end{array}$ & $\begin{array}{c}\text { Alternative methods } \\
\text { available to deal } \\
\text { with resource } \\
\text { shortage }\end{array}$ & $\begin{array}{l}\text { Production } \\
\text { technology easily } \\
\text { copes with } \\
\text { resource shortage }\end{array}$ \\
\hline$I_{8}$ & $\begin{array}{l}\text { High education } \\
\text { or training level }\end{array}$ & Low education or training level & No schooling & $\begin{array}{l}\text { Junior high school } \\
\text { or primary school }\end{array}$ & $\begin{array}{c}\text { Senior high school } \\
\text { or vocational } \\
\text { training }\end{array}$ & $\begin{array}{l}\text { Bachelor and } \\
\text { higher degrees }\end{array}$ \\
\hline$I_{9}$ & $\begin{array}{l}\text { High public } \\
\text { participation }\end{array}$ & Very little or no participation & $\begin{array}{l}\text { Less than } 30 \% \text { of } \\
\text { the public } \\
\text { satisfied with } \\
\text { participation in } \\
\text { governance }\end{array}$ & $\begin{array}{l}30-50 \% \text { of the } \\
\text { public satisfied } \\
\text { with participation } \\
\text { in governance }\end{array}$ & $\begin{array}{l}50-70 \% \text { of the } \\
\text { public satisfied with } \\
\text { participation in } \\
\text { governance }\end{array}$ & $\begin{array}{c}\text { More than } 70 \% \text { of } \\
\text { the public satisfied } \\
\text { with participation } \\
\text { in governance }\end{array}$ \\
\hline$I_{10}$ & $\begin{array}{c}\text { Diverse } \\
\text { linkages } \\
\text { between } \\
\text { organisations }\end{array}$ & Organisations work individually & No linkages & $\begin{array}{l}\text { Very weak } \\
\text { linkages }\end{array}$ & Some linkages exist & $\begin{array}{l}\text { Regular linkages } \\
\text { and close } \\
\text { relationships }\end{array}$ \\
\hline$I_{11}$ & $\begin{array}{l}\text { Equality for } \\
\text { most } \\
\text { stakeholders }\end{array}$ & Non-equality rules apply & Inequality & $\begin{array}{c}\text { Equality rules } \\
\text { seldom considered }\end{array}$ & $\begin{array}{l}\text { Equality criterion } \\
\text { exists but focus is } \\
\text { on benefits for } \\
\text { government }\end{array}$ & $\begin{array}{l}\text { Equality is a } \\
\text { criterion and is } \\
\text { applied to all } \\
\text { stakeholders }\end{array}$ \\
\hline$I_{12}$ & $\begin{array}{l}\text { Many social } \\
\text { groups }\end{array}$ & Lack of social groups & $\begin{array}{c}\text { No } \\
\text { environmental } \\
\text { NGOs }\end{array}$ & $\begin{array}{l}\text { Less NGOs than } \\
\text { in other cities in } \\
\text { the province }\end{array}$ & $\begin{array}{l}\text { Average number of } \\
\text { NGOs }\end{array}$ & $\begin{array}{l}\text { More NGOs than } \\
\text { in other cities in } \\
\text { the province }\end{array}$ \\
\hline$I_{13}$ & $\begin{array}{l}\text { Low illiteracy } \\
\text { rate }\end{array}$ & High illiteracy rate & $\begin{array}{l}\text { Higher than the } \\
\text { national average } \\
\text { level }(4.08 \%)\end{array}$ & $2.71 \%$ to $4.07 \%$ & $1.35 \%$ to $2.70 \%$ & $0 \%$ to $1.34 \%$ \\
\hline$I_{14}$ & $\begin{array}{l}\text { Habitat has not } \\
\text { changed } \\
\text { significantly }\end{array}$ & Habitat has changed dramatically & $\begin{array}{l}\text { More than } 35 \% \\
\text { of habitat change } \\
\text { compared to the } \\
\text { pre-dam period }\end{array}$ & $\begin{array}{l}21-35 \% \text { of habitat } \\
\text { change relative to } \\
\text { the pre-dam } \\
\text { period }\end{array}$ & $\begin{array}{l}6-20 \% \text { of habitat } \\
\text { change compared to } \\
\text { the pre-dam period }\end{array}$ & $\begin{array}{l}\text { Less than } 5 \% \\
\text { habitat change } \\
\text { compared to the } \\
\text { pre-dam period }\end{array}$ \\
\hline$I_{15}$ & $\begin{array}{l}\text { People very } \\
\text { concerned } \\
\text { about } \\
\text { environmental } \\
\text { changes }\end{array}$ & $\begin{array}{l}\text { People not concerned about } \\
\text { environmental changes }\end{array}$ & $\begin{array}{l}\text { No complaint } \\
\text { reports }\end{array}$ & $\begin{array}{l}\text { Smaller number } \\
\text { of complaint } \\
\text { reports than in } \\
\text { most cities in } \\
\text { Hunan Province }\end{array}$ & $\begin{array}{l}\text { The number of } \\
\text { complaint reports } \\
\text { comparable to the } \\
\text { other cities in Hunan } \\
\text { Province }\end{array}$ & $\begin{array}{l}\text { Higher number of } \\
\text { complaint reports } \\
\text { than most other } \\
\text { cities in Hunan } \\
\text { Province }\end{array}$ \\
\hline$I_{16}$ & $\begin{array}{l}\text { Spatial patterns } \\
\text { of core systems } \\
\text { are not changed }\end{array}$ & $\begin{array}{c}\text { Spatial patterns of core systems } \\
\text { are critically changed }\end{array}$ & $\begin{array}{l}\text { Changed and } \\
\text { cannot be } \\
\text { restored/renewed }\end{array}$ & $\begin{array}{l}\text { Changed in most } \\
\text { core systems with } \\
\text { long time to } \\
\text { reorganise }\end{array}$ & $\begin{array}{l}\text { Changed in some } \\
\text { core systems and } \\
\text { take short time to } \\
\text { reorganise }\end{array}$ & $\begin{array}{l}\text { Spatial patterns of } \\
\text { core systems are } \\
\text { not changed }\end{array}$ \\
\hline$I_{17}$ & $\begin{array}{l}\text { The activities } \\
\text { of social groups } \\
\text { receive high } \\
\text { attention }\end{array}$ & $\begin{array}{l}\text { Very little information to the } \\
\text { public about social groups }\end{array}$ & No news reports & $\begin{array}{l}\text { Low media } \\
\text { exposure } \\
\text { compared to other } \\
\text { cities in the } \\
\text { province }\end{array}$ & $\begin{array}{c}\text { Medium media } \\
\text { exposure compared } \\
\text { to other cities in the } \\
\text { province }\end{array}$ & $\begin{array}{l}\text { High media } \\
\text { exposure compared } \\
\text { to other cities in } \\
\text { the province }\end{array}$ \\
\hline$I_{18}$ & $\begin{array}{l}\text { Strong } \\
\text { leadership }\end{array}$ & Poor leadership & $\begin{array}{l}\text { Reputation of no } \\
\text { leadership }\end{array}$ & $\begin{array}{c}\text { Reputation at } \\
\text { local level }\end{array}$ & $\begin{array}{l}\text { Reputation at } \\
\text { provincial level }\end{array}$ & $\begin{array}{l}\text { Reputation at } \\
\text { national level }\end{array}$ \\
\hline
\end{tabular}




\subsubsection{Aggregation Process}

The process of aggregating the indicators involves defining suitable weights and modelling. They are discussed below.

\subsubsection{Indicator Weighting}

The hierarchical network presented in Figure 2 is used to determine the weights of all indicators. Table 5 shows the relationships between the core system components and indicators.

The core systems are critical for the state of SESs and the interrelationships between them are complex and difficult to isolate. Also, the established indicators are specific for particular components of the core subsystems according to the certainty of occurrence triggered by TGD (Xu et al., 2015a). They are representative of the SES' responses to particular changes - that is, each indicator uniquely contributes to a different aspect of the systems' resilience. Hence, they should be treated as equally important. Equal weights are assigned to all subsystems and indicators (see Figure 2). The actual calculation of weight, including $\omega_{S}$ - weights for respective subsystems $(S), \omega_{I}-$ weights for respective indicators for systems' abilities $(I)$ and $\omega_{P}$ - weights for respective indicators for policies $(P)$, is presented in Appendix 1 and the resulting values are listed in Table 6 .

Table 5. Relationship between core subsystems and indicators

\begin{tabular}{clccclcc}
\hline No. & Subsystem & $\begin{array}{c}\text { System } \\
\text { indicator }\end{array}$ & $\begin{array}{c}\text { Policy } \\
\text { indicator }\end{array}$ & No. & Subsystem & $\begin{array}{c}\text { System } \\
\text { indicator }\end{array}$ & $\begin{array}{c}\text { Policy } \\
\text { indicator }\end{array}$ \\
\hline 1 & RS1.1 & $I_{1}$ & $P_{1}$ & 15 & $\mathrm{GS} 1.3$ & $I_{9}$ & $P_{10}$ \\
2 & RS1.1 & $I_{2}$ & $P_{1}$ & 16 & $\mathrm{GS} 2.2$ & $I_{10}$ & $P_{11}$ \\
3 & RS1.2 & $I_{3}$ & $P_{2}$ & 17 & $\mathrm{GS} 3.2$ & $I_{11}$ & $P_{13}$ \\
4 & RS4 & $I_{4}$ & $P_{3}$ & 18 & $\mathrm{GS} 6.1$ & $I_{11}$ & $P_{13}$ \\
5 & RU4 & $I_{4}$ & $P_{2}, P_{3}$ & 19 & $\mathrm{U} 6.2$ & $I_{12}$ & $P_{14}$ \\
6 & RU1 & $I_{5}$ & $P_{1}, P_{2}, P_{3}$ & 20 & $\mathrm{U} 7$ & $I_{13}$ & $P_{15}$ \\
7 & RU5.2 & $I_{5}$ & $P_{1}, P_{2}, P_{3}$ & 21 & $\mathrm{RS} 1.4$ & $I_{14}$ & $P_{17}$ \\
8 & RS1.3 & $I_{5}$ & $P_{7}, P_{8}$ & 22 & $\mathrm{RS} 5$ & $I_{15}$ & $P_{18}$ \\
9 & RU3 & $I_{6}$ & $P_{4}$ & 23 & $\mathrm{RU} 5.1$ & $I_{16}$ & $P_{9}$ \\
10 & RU3 & $I_{7}$ & $P_{5}$ & 24 & $\mathrm{U} 5$ & $I_{17}$ & $P_{19}$ \\
11 & U1 & $I_{8}$ & $P_{6}$ & 25 & $\mathrm{U} 5$ & $I_{18}$ & $P_{19}$ \\
12 & U8.1 & $I_{8}$ & $P_{6}$ & 26 & RU2 & & $P_{9}$ \\
13 & GS1.1 & $I_{9}$ & $P_{10}$ & 27 & GS3.1 & & $P_{12}$ \\
14 & GS1.2 & $I_{9}$ & $P_{10}$ & 28 & $\mathrm{U} 8.2$ & & $P_{16}$ \\
\hline
\end{tabular}

Table 6. Weights of indicators for the studied SESs

\begin{tabular}{lccccccccccc}
\hline \multicolumn{1}{c}{$\boldsymbol{S}$} & $\boldsymbol{\omega}_{\boldsymbol{S}}$ & $\boldsymbol{I}$ & $\boldsymbol{\omega}_{\boldsymbol{I}}$ & $\boldsymbol{P}$ & $\boldsymbol{\omega}_{\boldsymbol{P}}$ & \multicolumn{1}{c}{$\boldsymbol{S}$} & $\boldsymbol{\omega}_{\boldsymbol{S}}$ & $\boldsymbol{I}$ & $\boldsymbol{\omega}_{\boldsymbol{I}}$ & $\boldsymbol{P}$ & $\boldsymbol{\omega}_{\boldsymbol{P}}$ \\
\hline RS1.1 & 0.071 & $I_{1}$ & 0.019 & $P_{1}$ & 0.058 & $\mathrm{GS} 2.2$ & 0.036 & $I_{14}$ & 0.019 & $P_{14}$ & 0.019 \\
RS1.2 & 0.036 & $I_{2}$ & 0.019 & $P_{2}$ & 0.048 & $\mathrm{GS} 3.2$ & 0.036 & $I_{15}$ & 0.019 & $P_{15}$ & 0.019 \\
RS4 & 0.036 & $I_{3}$ & 0.019 & $P_{3}$ & 0.048 & $\mathrm{GS6} 6.1$ & 0.036 & $I_{16}$ & 0.019 & $P_{16}$ & 0.019 \\
RU4 & 0.036 & $I_{4}$ & 0.033 & $P_{4}$ & 0.019 & $\mathrm{U} 6.2$ & 0.036 & $I_{17}$ & 0.019 & $P_{17}$ & 0.019 \\
RU1 & 0.036 & $I_{5}$ & 0.033 & $P_{5}$ & 0.019 & $\mathrm{U} 7$ & 0.036 & $I_{18}$ & 0.019 & $P_{18}$ & 0.019 \\
RU5.2 & 0.036 & $I_{6}$ & 0.019 & $P_{6}$ & 0.037 & $\mathrm{RS} 1.4$ & 0.036 & & & $P_{19}$ & 0.037 \\
RS1.3 & 0.036 & $I_{7}$ & 0.019 & $P_{7}$ & 0.012 & RS5 & 0.036 & & & & \\
RU3 & 0.071 & $I_{8}$ & 0.037 & $P_{8}$ & 0.012 & RU5.1 & 0.036 & & & & \\
U1 & 0.036 & $I_{9}$ & 0.058 & $P_{9}$ & 0.037 & U5 & 0.071 & & & & \\
U8.1 & 0.036 & $I_{10}$ & 0.019 & $P_{10}$ & 0.058 & RU2 & 0.036 & & & & \\
GS1.1 & 0.036 & $I_{11}$ & 0.037 & $P_{11}$ & 0.019 & GS3.1 & 0.036 & & & & \\
GS1.2 & 0.036 & $I_{12}$ & 0.019 & $P_{12}$ & 0.019 & U8.2 & 0.036 & & & & \\
GS1.3 & 0.036 & $I_{13}$ & 0.019 & $P_{13}$ & 0.037 & & & & & & \\
\hline
\end{tabular}


For the SESs of the studied area, 37 indicators $(m=18 ; k=19)$ are used to assess the three areas $u(u=1,2,3)$ of the Dongting Lake region, namely ED, WD and SD. Most indicators for certain and potential changes are positive meaning that the higher their scores the higher the resilience of the system. The indicators for unknown changes however are negative meaning that they are not expected to change (see Table 1), the smaller their scores, the higher the resilience. On the other hand, all policy indicators $P_{b}$ are positive and divided into three levels ("not resilient", "low resilience", "medium resilience" and "high resilience").

\subsubsection{Aggregation modelling}

The desirable states of SESs are the ones that are close to high resilience and away from undesirable and unsustainable regimes. This means the states of the systems should have the shortest distance from the positive state (high resilience or sustainable) and the longest distance from the negative state (low resilience or unsustainable). Such a requirement matches well the core concept of the technique for ordering preferences according to their similarity to the ideal solution (TOPSIS) (Hwang \& Yoon, 1981) used in multi-criteria decision analysis modelling. The approach is based on the idea that the optimal resolution should have the shortest distance from the ideal solution and the farthest from the negative solution. It has proven useful in complex environmental assessments when compensating for data limitation through fuzzy linguistic descriptions (Chen, 2000).

The weighted TOPSIS method applied in this study allows for the lake areas to be ranked according to preference based on the value of the relative closeness $\left(C^{*}\right)$ to the ideal solutions for the indicators (refer to Append 2 for further details). Using the value of $C^{*}$ the ranking is in a descending order starting from the best performance.

\section{Results}

\subsection{Indicator Scoring}

Quantitative values were obtained for the indicators which could be measured or for which statistical information was available. In addition, the experts were asked to assign scores to the remaining indicators. The obtained results are presented in Table 7 where 1 represents "not resilient", 2 - "low resilience", 3 - "medium resilience" and 4 - "high resilience").

Table 7. Values of indicators

\begin{tabular}{|c|c|c|c|c|c|c|c|}
\hline \multirow{2}{*}{ Indicator } & \multicolumn{3}{|c|}{$\mathbf{U}$} & \multirow{2}{*}{ Indicator } & \multicolumn{3}{|c|}{$\mathbf{U}$} \\
\hline & ED & SD & WD & & ED & SD & WD \\
\hline$I_{1}$ & 24.94 & 29.5 & 30.02 & $P_{1}$ & 2 & 2 & 2 \\
\hline$I_{2}$ & 0.95 & 0.84 & 0.81 & $P_{2}$ & 3 & 3 & 3 \\
\hline$I_{3}$ & 4 & 3 & 3 & $P_{3}$ & 4 & 4 & 4 \\
\hline$I_{4}$ & 3 & 3 & 3 & $P_{4}$ & 3 & 3 & 3 \\
\hline$I_{5}$ & 4 & 3 & 3 & $P_{5}$ & 3 & 3 & 3 \\
\hline$I_{6}$ & 2.5 & 2.41 & 2.63 & $P_{6}$ & 3 & 3 & 3 \\
\hline$I_{7}$ & 3 & 2 & 2 & $P_{7}$ & 2 & 2 & 2 \\
\hline$I_{8}$ & 2 & 2 & 2 & $P_{8}$ & 2 & 2 & 2 \\
\hline$I_{9}$ & 2 & 2 & 2 & $P_{9}$ & 3 & 3 & 3 \\
\hline$I_{10}$ & 4 & 3 & 3 & $P_{10}$ & 1 & 1 & 1 \\
\hline$I_{11}$ & 3 & 3 & 3 & $P_{11}$ & 2 & 2 & 2 \\
\hline$I_{12}$ & 3 & 3 & 3 & $P_{12}$ & 3 & 3 & 3 \\
\hline$I_{13}$ & 1.76 & 2.32 & 3.20 & $P_{13}$ & 3 & 3 & 3 \\
\hline$I_{14}$ & 4 & 3 & 3 & $P_{14}$ & 2 & 2 & 2 \\
\hline$I_{15}$ & 3 & 3 & 4 & $P_{15}$ & 4 & 4 & 4 \\
\hline$I_{16}$ & 3 & 4 & 4 & $P_{16}$ & 1 & 1 & 1 \\
\hline$I_{17}$ & 4 & 2 & 3 & $P_{17}$ & 3 & 3 & 3 \\
\hline \multirow{2}{*}{$I_{18}$} & \multirow{2}{*}{4} & \multirow{2}{*}{2} & \multirow{2}{*}{3} & $P_{18}$ & 3 & 3 & 3 \\
\hline & & & & $P_{19}$ & 1 & 1 & 1 \\
\hline
\end{tabular}


The average monthly water level in Chenglingji was $24.94 \mathrm{~m}$ between 2003 and 2008 which was a $0.43 \mathrm{~m}$ decrease compared to $25.37 \mathrm{~m}$ in 1981-2002 prior to the operation of the dam (Y. Li, $2014 \mathrm{pp} 198)$. Water shortage is more serious for SD and WD. During 2003-2008, the average water level in the Nanzui and Xiaohezui monitoring stations in SD and WD was $30.02 \mathrm{~m}$ and $29.5 \mathrm{~m}$ respectively (X. Wang, Xiao, Zhu, \& Shi, 2012) a reduction by $0.93 \mathrm{~m}$ and $1.01 \mathrm{~m}$ respectively compared to the period before the operation of the dam (Tong, Han, Lei, \& Li, 2014).

Water demands of the SESs in the Dongting Lake region include ecological, agricultural, industrial and domestic requirements. According to Tong et al. (2014), the 2006 total average water demands in WD, SD and ED were respectively $1.22,1.34$ and 1.38 billion $\mathrm{m}^{3}$ with increasing trends. The supplies for these three regions are 0.99 , 1.13 and 1.32 billion $\mathrm{m}^{3}$ and the basic ecological water demand of Dongting Lake is estimated at 0.27 billion $^{3}$ (Tong et al., 2014). With priority given to ecological demands, there are gaps in meeting the needs for socioeconomic development in all areas of the lake. The supply-demand ratios are 0.81 for WD, 0.84 for SD and 0.95 for ED with water shortages being common. Without effective adaptation, the gap will continue to increase especially for SD and WD.

Since the operation of the TGD and lower water level caused by the impoundment of the dam, key resources of the lake such as waterbirds, fish and Carex brevicuspis are all decreasing due to declining liveable spaces. More specifically, the impoundment of the TGD leads to the earlier appearance of emergent macrophytes causing large parts of the lands and Carex brevicuspis to become dry and withered at the time of arrival of the migratory waterbirds. Such an early dry-up results in shortage of food sources for the waterbirds of the lake. From the 300-400 thousands waterbirds who used to live in the lake decades ago, about 130 thousands were seen between 2003 and 2004, less than 100 thousands between 2005 and 2006 (cited in Tong et al., 2014), and about 110 thousands between 2008 and 2009 (Xie, Zhang, \& Jiang, 2014). Due to fragmented data, expert scoring was used for the assessment of $I_{5}$. The majority of the participating experts, namely 12 out of 20, agreed that the liveable space for key resources (fish, vegetation distribution and waterbirds) of the lake has reduced because of the TGD disturbance. Although parts of the disturbed spaces in the ED areas recover with further adaptations, the situation is worse in SD and WD because of more severe water shortage.

According to 2003-2008 statistical data, the average urban-rural gaps $\left(I_{6}\right)$ were 2.50, 2.41, and 2.63 for ED, SD, and WD respectively (S. Li, N. Li, \& L. Li, 2014). The experts' average scores for $I_{7}$ are 3, 2 and 2 meaning medium resilience for ED and low resilience for SD and WD. Despite the values for both agriculture and fishery increasing in the three areas between 2003 and 2008, the production methods are still at a low level with technology lacking in the region (S. Li et al., 2014).

With regards to $I_{8}$, the number of people in Yueyang City with junior high and primary school qualifications, senior high school and vocational training qualifications, and bachelor degrees were respectively $3.4,1.3$ and 0.4 million persons (Regional bulletins of the sixth nationwide population census, 2011). In Yiyang and Changde cities, these numbers were 3, 0.7 and 0.1 and 3.9, 1 and 0.4 million persons (Regional bulletins of the sixth nationwide population census, 2011). The education attainment of the three areas is similar and at a low level, which is also in accord with the experts' scoring.

During the field survey, the stakeholders were asked whether they were satisfied with the involvement of local people in government decision-making $\left(I_{9}\right)$. Only 5 out of 20 stated that they were satisfied with public participation strategies in the ED area. Some regulations have been put in place to enhance public participation at a provincial level; for example, the Regulations for Governance Procedures of Hunan Province give residents, representatives of enterprises and other organisations rights to participate in and propose rules of governance (Hunan Government, 2008). Their implementation however is ineffective. Most local stakeholders stated that the participating people did not represent them, did not know that the government called for local resident participation or who attended these events. Some fishers claimed that participation opportunities are not equal to everyone: doors open easier for licenced fishers but semi-fishers (who do not have licence but also have rights to fish in the lake in specific months of the year) have very few ways to get involved. The public is not satisfied with participation because of poor feedback from government. This was also confirmed by the analysis of information and documents related to public participation in the Dongting Lake areas which showed very narrow ways for participating in decision making. A similar situation exists for the SD and WD areas as their upper governance departments are affiliated with Hunan Province. The experts confirmed this problem: 17 (out of 20) are of the opinion that the degree of public participation is very low in the three regions and gave low scores. Experts scored the equality of stakeholders involved $\left(I_{l l}\right)$ higher as the government uses this criterion in selecting stakeholders but mainly for its own benefits. 
The average expert scores for the linkages of social networks are respectively 4, 3 and 3 for ED, SD and WD. Special events periodically held in the lake areas confirm this. For example, the Dongting Lake International Bird Watching Festival is held in ED in December of each year, Love Birds Week events are organised in SD and WD, research collaboration exists between the Dongting Lake Reserve Authorities, universities, institutes and the Wold Wildlife Fund for Nature (WWF).

The number of environmental NGOs is used as a surrogate for the size of social groups $\left(I_{12}\right)$. Experts gave a higher score for Yueyang city (located in the ED area) than that for Yiyang and Changde cities (in SD and WD). The All-China Environment Federation database (2014) shows that the total number of registered environmental NGOs in Hunan Province is 126, of which Changsha, the capital of the province, accounts for $68 \%$. Except Changsha (which is outside the study area, with a total number at 14 the three cities of Dongting Lake have more registered NGOs than most other cities: Yueyang City has 6 (the third highest number in Hunan Province after Changsha and Hengyang both with 7), Changde -5 and Yiyang -3 .

Both habitat loss and fragmentation increase the probability of species (such as birds and fish) leaving their habitat and entering another hostile place where their overall mortality rate increases. Habitat loss which is more significant than habitat fragmentation can also result in reduction in reproduction (Fahrig, 2002). According to Yang (2013), the habitat of Dongting Lake has begun to fragment since 1987 and this has accelerated especially since 2003. The total number of patches of the lake has increased from 16350 in 1998 to 19564 in 2008. However, the average area coverage of the patches has decreased from about $1.58 \mathrm{~km}^{2}$ in 1998 to $1.32 \mathrm{~km}^{2}$ in 2008. A key place for most species is ED which provides habitat for $80.92 \%$ of the total waterbirds of the lake while SD and WD account respectively for $2.68 \%$ and $3.45 \%$ (Xie et al., 2014). Since the operation of the dam, the habitat areas for critical waterbirds (such as cranes) have dramatically decreased, particularly in ED. The experts scored changes in habitat higher for ED than in SD and WD (4, 3 and 3 respectively).

The number of complaint reports $\left(I_{15}\right)$ data was obtained from the 2013-2014 Environmental Protection Department of Hunan. We counted the online complaints made on the website of the Department and compared the data with all cities in the province. In Hunan Province, Changde is the third highest city according to frequency of complaints (with an average rank of 17.5 for 2013 and 2014) made through the Department's online system. Yueyang and Yiyang cities were in the middle of the ranked 14 and 13.5 respectively. The three areas consequently scored 4 (WD), 3(ED) and 3(SD).

According to the experts, the spatial patterns of the core systems in three areas have somewhat changed due to alteration in the hydrological conditions. These changes are much severer in SD and WD which have lower water supplies compared to the period prior to the operation of the dam. Thus, experts scored 3, 4 and 4 for ED, $\mathrm{SD}$ and WD respectively.

China's online search engine Baidu was used to analyse media exposure of environmental NGOs in Hunan Province. Yueyang is the second highest ranked city with number of times its NGOs reported in the mass media being 74, which is far more often than the others -Zhuzhou with 19. Changde with 10 and Yiyang with 3 . With respect to the power of the leading local social groups $\left(I_{18}\right)$, the experts from Hunan Province saw the environmental NGOs in Yueyang as the most well-known not only in the region but also at the national level. The leader (Zaibao Zhu) of the biggest NGO in Yueyang has a high reputation and he has been involved in environmental protection activities in the past 35 years despite health drawbacks (he was diagnosed with gastric cancer 20 years ago). The respective scores experts are 4 for ED, 2 for SD and 3 for WD.

Most policies apply to the whole lake with very little differences between the three areas. Hence they received the same scores (see Table 3 and 7).

\subsection{Social-ecological Resilience of Dongting Lake Region}

With the relative distance valued between 0 and 1 , five levels were introduced to describe the level of social-ecological resilience of the Dongting Lake areas (see Table 8). Table 9 presents the results for the resilience of the SESs of Dongting Lake based on the established weights and values of the indicators (in Tables 6 and 7) and aggregation model (in Appendix 2). The social-ecological resilience of ED is the highest among the three areas with a relative closeness of less than 0.1 to the ideal high level; SD and WD have relatively low resilience in the face of the perturbation of TGD. Although the estimated social-ecological resilience for SD and WD is at the same level, WD is better than SD being 0.1 closer to the positive ideal solution (see Table 9). 
Table 8. Assessment criteria for resilience of SESs

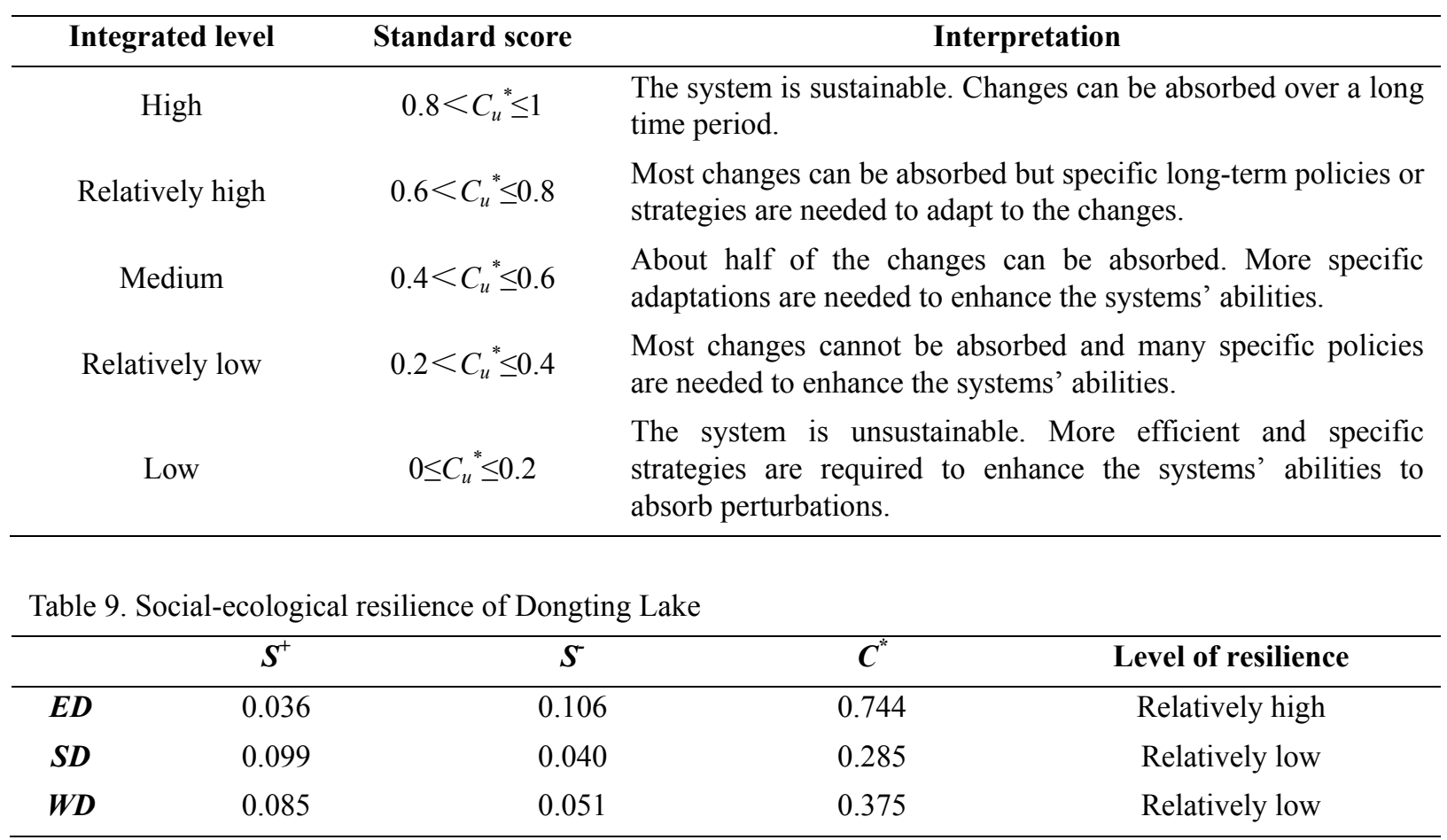

Note: $S^{+}$- desirable state of high resilience; $S$ - undesirable state of non-resilience.

\section{Discussion}

Since its impoundment, not only has the TGD impacted Dongting Lake's ecological systems, it has also affected its socioeconomic systems. Overall, ED has stronger abilities to absorb most changes but specific long-term policies and strategies are needed for better adaptation. The diversity of stakeholder networks $\left(I_{10}\right)$ in the region is assessed to be at a high level in the ED area, including regular activities collaboratively organised by NGOs and local government such as the Love Birds Week event. However, the policy support to local NGOs $\left(P_{l 1}\right)$ is basic and a variety of measures are needed to enhance the social networks' power in long-term adaptation. By comparison, SD and WD are more vulnerable in responding to perturbations from the TGD with many aspects needed strengthening. For example, production methods in both areas are simple and technological support is needed to improve the locals' production level $\left(I_{7}\right)$. Also, social groups and their leadership should be encouraged and seen as more important for the purposes of environmental protection and adaptation. The study revealed a large number of universities-based environmental NGOs; however, their media coverage is small. This might indicate that their contribution to environmental protection activities is also small with the biggest barrier being insufficient funding support. More financial support for NGOs could enable them to make a real difference.

The reasons for ED having a higher resilience than the other two areas can be explained along three aspects. First of all, the topographical differences in the three areas make ED more ecologically resilient to the reduced water level. The landform of the bottom of ED is lower than in SD and WD, which gives the "U" shape topography of Dongting Lake - the water slopes from northwest to southeast. Thus, the water coverage area in ED is the largest (about $1327.8 \mathrm{~km}^{2}$ ) among the three $\left(920 \mathrm{~km}^{2}\right.$ for SD and $443.4 \mathrm{~km}^{2}$ for WD) (S. Li et al., $\left.2014 \mathrm{pp} .87-88\right)$. All water going into the lake discharges into the YR through the outlet at Chenglingji (ED). When the water supply from the YR to the lake through the inlets (Songzi, Taiping, and Ouchi) dries up, water scarcity becomes more serious for SD and WD.

Secondly, economic growth in ED is faster than SD and WD which makes this are more adaptive to external disturbances, especially its socioeconomic systems. The output values for primary, secondary and tertiary industries in Yueyang City (ED) in 2010 were $0.22,0.83$ and 0.49 billion Yuan. In Yiyang City (SD) the respective values were Y0.16, 0.29 and 0.26 billion Yuan while in Changde City (WD) they were $0.28,0.69$ and 0.53 billion Yuan (Yearbook of Hunan Province, 2011). The good economic situation of Yueyang City gives the ED area higher abilities to adapt to changes. This is in line with Rose and Liao (2005) and Alessa et al. (2008) 
who claim that wealthier communities have higher resilience in absorbing disturbances and changes. Hence, the current development plan for a Dongting Lake Ecological Economic Zone may be able to contribute for improving the livelihoods of the communities around the lake. Development emphasises should also be given to SD and WD in a way that strengthens their traditional economic activities, such as increasing agricultural productivity through innovative technology support, and supports innovative industries that are less resources-based, eco-friendly and economically efficient, such as eco-tourism and biomedical industries (which can potentially use wastes from the catchment).

Thirdly, the ED's social and natural capitals improve its resilience abilities. Labour capital in Yueyang City is of higher quality with the proportion of people in the labour force who have at least college qualification being $11.9 \%$ compared to $8.8 \%$ in Yiyang and $11.1 \%$ in Changde. Geographically. ED has the largest area with $1900 \mathrm{~km}^{2}$ followed by SD with $1600 \mathrm{~km}^{2}$ and WD with only $350 \mathrm{~km}^{2}$. A larger area means more resources. The total habitat coverage in ED is $400 \mathrm{~km}^{2}$ while it is $300 \mathrm{~km}^{2}$ in SD and $150 \mathrm{~km}^{2}$ in WD. Between 2008 and 2009, there were respectively 88239, 2918 and 3762 waterbirds living in ED, SD and WD, accounting for $80.92 \%, 2.68 \%$ and $3.45 \%$ of total waterbirds of the lake (S. Li et al., 2014; Xie et al., 2014). To enhance the resilience of SD and WD, policy priority has to be given to restoration and protection strategies, including resource protection plans and reproduction plans for the fish. Increasing the quality of the labour force is also essential for enhancing the social resilience in the SD and WD regions, not only relying on school education but also offering professional training to residents and workers by local government officers.

Nevertheless, the three regions also face some common issues. First, the water exchange between the lake and joint rivers is generally unbalanced. Water inflows to the lake overweigh its outflows. The average monthly water level in Chenglingji between 2003 and 2008 shows low water levels and shortage in the lake from December to March (wet season). Water levels during these months were all lower than $23 \mathrm{~m}$ with the lowest at $21 \mathrm{~m}$ in January while in the wet season the water levels used to be nearly $29 \mathrm{~m}$. The TGD actually expended the duration of drought in the lake regions and reduced its resilience in dry seasons. Policy responses to such change are still being debated. Water adjustment options need to be finalised as soon as possible for effective adaptation to the declining water levels.

Second, the low educational attainment of the people in the lake region contributes to low resilience. Further attempts need to be made to improve the education and professional training of local residents to increase their ability to learn new knowledge and skills for effective adaptation to environmental changes. Third, public participation in policy making has to be extended and made more effective as well as representative of all stakeholders. Although governmental regulation exist at provincial level (Hunan Government, 2008), public participation is not always conducted properly with all stakeholders identified. Fourth, there is still a dearth of diversity in strategies and policies to respond specifically to the disturbance of the TGD. For example, the support for local environmental NGOs should be financial at a sufficient level for effective operation as well as through giving them appropriate rights. There is more potential for NGOs to contribute for effective regional adaptation.

\section{Conclusion}

The TGD has delivered significant socioeconomic benefits to the Dongting Lake region. However, its negative impacts on the river-lake interactions through alterations in the hydrological conditions and ecological systems should not be ignored. The assessment on the link between the dam and joint lakes should not only focus separately on ecological or socioeconomic systems but on the combined SESs due to the high dependency of the communities on the lake and the impact they have on it. The resilience of the SESs of the lake areas can indicate the changes triggered by the dam to the socioeconomic systems and the responses and abilities of SESs to absorb these changes.

This study conducted an integrated assessment on the social-ecological resilience of Dongting Lake. The assessment was based on a set of social-ecological resilience indicators developed by Xu et al. (2015a) which were applied to three parts of the lake - east (ED), west (WD) and south (SD). Its results demonstrate that ED has the highest resilience with the most ability to absorb current and future perturbations caused by TGD to its social-ecological system. The existing policy responses however are basic with more diverse strategies needed to improve the resilience of the lake's communities and the power of social groups. With the social-ecological resilience of SD and WD at a relatively low level, more strategies are required to enhance the systems' absorption abilities (including improvement in productions technologies, education and professional training for local people, and public participation in policy makings) as well as to diversify the policy responses including 
support for local social groups and NGOs and planning for the protection of the lake's food chains. Effective adaptation measures can improve the lake's resilience and support its long-term sustainability.

\section{Acknowledgments}

The first author would like to acknowledge the financial support of CUSPA (Curtin University) for the field surveys of this study. All authors express their appreciation of the participation of experts from the Department of Fisheries of Dongting Lake, Dongting Lake Station for Wetland Ecosystem Research of the Chinese Academy of Sciences, Hohai University and Nanjing Institute of Geography and Limnology of the Chinese Academy of Sciences and Nanjing Technology University.

\section{References}

Alessa, L., Kliskey, A., Lammers, R., Arp, C., White, D., Hinzman, L., \& Busey, R. (2008). The Arctic water resource vulnerability index: an integrated assessment tool for community resilience and vulnerability with $\begin{array}{llll}\text { respect to } & \text { freshwater. Environmental }\end{array}$ http://dx.doi.org/10.1007/s00267-008-9152-0

$\begin{array}{llll}\text { All-China } & \text { Environment } & \text { Federation. } & \text { (2014). }\end{array}$ http://www.acef.com.cn/ngohy/2014/0115/11413.html

Berkes, F. (2007). Understanding uncertainty and reducing vulnerability: lessons from resilience thinking. Natural Hazards, 41, 283-295. http://dx.doi.org/10.1007/s11069-006-9036-7

Berkes, F., \& Folke, C. (Eds). (1998). Linking social and ecological systems: Management and practices and social mechanisms. Cambridge, UK: Cambridge University Press.

Biswas, A. K. (1991). Water for sustainable development in the 21st century: a global perspective. GeoJournal, 24(4), 341-345. http://dx.doi.org/10.1007/BF00578255

Cabell, J. F., \& Oelofse, M. (2012). An indicator framework for assessing agroecosystem resilience. Ecology and Society, 17(1), 18. http://dx.doi.org/10.5751/ES-04666-170118

Carpenter, S. R., \& Cottingham, K. L. (1997). Resilience and restoration of lakes. Conservation Ecology, 1(1), 2. Retrieved from http://www.consecol.org/vol1/iss1/art2/

Carpenter, S. R., Brock, W. A., \& Hanson, P. C. (1999). Ecological and social dynamics in simple models of ecosystem management. Conservation Ecology, 3(2), 4. Retrieved from http://www.consecol.org/vol3/iss2/art4/

Carpenter, S. R., Ludwig, D., \& Brock, W. (1999). Management of eutrophication for lakes subject to potentially $\begin{array}{lllll}\text { irreversible } \quad \text { change. } & \text { Ecological }\end{array}$ http://dx.doi.org/10.1890/1051-0761(1999)009[0751:MOEFLS]2.0.CO;2

Chen, C. T. (2000). Extensions of the TOPSIS for group decision-making under fuzzy environment. Fuzzy Sets and Systems, 114, 1-9. http://dx.doi.org/10.1016/S0165-0114(97)00377-1

Deng, F., Wang, X., Cai, X., Li, E., Jiang, L., Li, H., \& Yan, R. (2014). Analysis of the relationship between inundation frequency and wetland vegetation in Dongting Lake using remote sensing data. Ecohydology, 7(2), 717-726. http://dx.doi.org/10.1002/eco.1393

Environmental Protection Department of Hunan. (2013-2014). Retrieved from http://www.hbt.hunan.gov.cn/

Fahrig, L. (2002). Effect of habitat fragmentation on the extinction threshold: a synthesis. Ecological Applications, 12(2), 346-353. http://dx.doi.org/10.1890/1051-0761(2002)012[0346:EOHFOT]2.0.CO;2

Feng, L., Hu, C., Chen, X., \& Zhao, X. (2013). Dramatic inundation changes of China's two largest freshwater lakes linked to the Three Gorges Dam. Environmental Science \& Technology, 47, 9628-9634. http://dx.doi.org/10.1021/es4009618

Gleick, P. H., Ajami, N., Christian-Smith, J., Cooley, H., Donnelly, K., Fulton, J. ... Srinivasan, V. (2014). The World's Water Volume 8: the Biennial Report on freshwater resources. Island Press, Washington DC.

Hunan Government. (2008). Retrieved http://www.hunan.gov.cn/xxgk/fz/zy/200809/t20080912_251101.html

Hwang, C. L., \& Yoon, K. (1981). Multiple attribute decision making: methods and applications. Springer, Berlin Heidelberg.

Johnson, N., Revenga, C., \& Echeverria, J. (2001). Managing water for people and nature. Science, 292(5519). http://dx.doi.org/1071-1072. 10.1126/science.1058821 
Jorgensen, S. E. (2008). Freshwater Lakes. Reference Module in Earth Systems and Environmental Sciences $\begin{array}{lllll}\text { Encyclopaedia of Ecology. ScienceDirect } & \text { (Online), }\end{array}$ http://dx.doi.org/10.1016/B978-008045405-4.00339-6

Kingsford, R. T. (2000). Ecological impacts of dams, water diversions and river management on floodplain $\begin{array}{lllll}\text { wetlands in Australia. } & \text { Austral }\end{array}$ http://dx.doi.org/10.1046/j.1442-9993.2000.01036.x

Kuijs, L., \& Wang, T. (2006). China's pattern of growth: moving to sustainability and reducing inequality. China \& World Economy, 14(1), 1-14. http://dx.doi.org/10.1111/j.1749-124X.2006.00003.x

Lai, X., Jiang, J., \& Huang, Q. (2013). Effects of the normal operation of the Three Gorges Reservoir on wetland inundation in Dongting Lake, China: a modelling study. Hydrological Sciences Journal, 58(7), 1467-1477. http://dx.doi.org/10.1080/02626667.2013.831418

Lajoie, F., Assani, A. A., Roy, A. G., \& Mesfioui, M. (2007). Impacts of dams on monthly flow characteristics. The influence of watershed size and seasons. Journal of Hydrology, 334(3), 423-439. http://dx.doi.org/10.1016/j.jhydrol.2006.10.019

Leitch, A. M., \& Bohensky, E. L. (2014). Return to 'a new normal': discourses of resilience to natural disasters in Australian newspapers 2006-2010. Global Environmental Change, 26, 14-26. http://dx.doi.org/10.1016/j.gloenvcha.2014.03.006

Li, S., Li, N., \& Li, L. (2014). Study of adjustment to industrial structure in Dongting Lake areas. In the Research Series of Dongting Lake Ecological Economic Zone. Hunan University Press, Changsha, China.

Li, Y. (2014). History of Dongting Lake: transformation, development and governance. In The research series of Dongting Lake Ecological Economic Zone. Hunan University Press, Changsha, China.

Liu, Y., Wu, G., \& Zhao, X. (2013). Recent declines in China's largest freshwater lake: trend or regime shift? Environmental Research Letters, 8, 1-9. http://dx.doi.org/10.1088/1748-9326/8/1/014010

Ministry of Water Resources of China. (2014). 2013 Statistic Bulletin on China Water Activities. China Water \& Power Press.

Newman P., Beatley T., \& Boyer, H. (2009). Resilient cities: responding to peak oil and climate change. Island Press, Washington DC

Nystrom, M., Folke, C., \& Mogerg, F. (2000). Coral reef disturbance and resilience in a human-dominated $\begin{array}{lllll}\text { environment. Trends in Ecology \& Evolution, 15(10), 413-417. } & \text {. }\end{array}$ http://dx.doi.org/10.1016/S0169-5347(00)01948-0

Ostrom, E. (1990). Governing the Commons: The Evolution of Institutions for collective Action. Cambridge University Press.

Regional bulletins of the sixth nationwide population census. (2011). Retrieved from http://www.hntj.gov.cn/sxfx/

Reid, D., \& Beeton, A. (1992). Large lakes of the world: A global science opportunity. GeoJournal, 28(1), 67-72. http://dx.doi.org/10.1007/BF00216408

Rose, A., \& Liao, S. (2005). Modelling regional economic resilience to disaster: a computable general equilibrium analysis of water service disruptions. Journal of Regional Science, 45(1), 75-112. http://dx.doi.org/10.1111/j.0022-4146.2005.00365.x

Scheffer, M., Brock, W. A., \& Westley, F. (2000). Mechanisms preventing optimum use of ecosystem services: an interdisciplinary theoretical analysis. Ecosystems, 3, 451-471. http://dx.doi.org/10.1007/s100210000040

Tong, Q., Han, W., Lei, F., \& Li, B. (2014). Jiejue Dongtinghuqu Jijiexing Queshui Fangan Bijiao Yanjiu. In The research series of Dongting Lake ecological economic zone (in Chinese). Hunan University Press, Changsha China.

Tullos, D. (2009). Assessing the influence of environmental impact of assessments on science and policy: an analysis of the Three Gorges Project. Journal of Environmental Management, 90, S208-S223. http://dx.doi.org/10.1016/j.jenvman.2008.07.031

Walker, B. (2014). Montpellier Resilience conference 2014. Accessed on the web of Stockholm Resilience Centre. Retrieved from http://www.stockholmresilience.org/21/research.html 
Walker, B. H., Abel, N., Anderies, J. M., \& Ryan, P. (2009). Resilience, adaptability, and transformability in the Goulburn-Broken catchment Australia. Ecology and Society, 14(1), 12. Retrieved from http://www.ecologyandsociety.org/vol14/iss1/art12/

Walker, B., Carpenter, S., Anderies, J., Abel, N., Cumming, G., Janssen, M., ... Pritchard, R. (2002). Resilience management in social-ecological systems: a working hypothesis for a participatory approach. Conservation Ecology, 6(1), 14. Retrieved from http://www.consecol.org/vol6/iss1/art14/

Walker, B., Gunderson, L., Kinzig, A., Folke, C., Carpenter, S., \& Schultz, L. (2006). A handful of heuristics and some propositions for understanding resilience in social-ecological systems. Ecology and Society, 11(1), 13. Retrieved from http://www.ecologyandsociety.org/vol11/iss1/art13/

Wang, P., Lassoie, J.P., Dong, S., \& Morreale, S.J. (2013). A framework for social impact analysis of large dams: a caase study of cascading dams on the Upper-Mekong River, China. Journal of Environmental Management, 117, 131-140. http://dx.doi.org/10.1016/j.jenvman.2012.12.045

Wang, X., Xiao, W., Zhu, W., \& Shi, X. (2012). Effects of water level variation on water quality in Dongting Lake (in Chinese). South-to-North Water Transfers and Water Science \& Technology, 10(5), 59-62.

Wetlands China. (2011). Retrieved from http://www.shidi.org/sf_E66E6CA3A55A4212A0FABD96C934A8AD_151_xdthzrbhqglj.html

Xie, Y., Zhang, S., \& Jiang, Y. (2014). Evolution of Ecological environments in Dongting Lake wetlands (in Chinese). Hunan Science \& Technology Press, Changsha, China.

Xinhua Net. (2009). Retrieved from http://midchina.xinhuanet.com/2009-11/14/content_18231205.htm

Xinhua Net. (2009). Retrieved from http://www.xinhuanet.com/chinanews/2009-10/20/content_17994572.htm

Xu, L., \& Marinova, D. (2013). Resilience thinking: a bibliometric analysis of socio-ecological research. Scientometrics, 96(3), 911-927. http://dx.doi.org/10.1007/s11192-013-0957-0

Xu, L., Marinova, D., \& Guo, X. (2015b). Resilience thinking: a renewed system approach for sustainability science. Sustainability Science, 10(1), 123-138. http://dx.doi.org/10.1007/s11625-014-0274-4

Xu, L., Marinova, D., Xin, P., \& Guo, X. (2015a). Resilience-oriented sustainability indicators for freshwater lakes with application for Dongting Lake, China. Environment and Natural Resources Research, 5(2), 148-171. http://dx.doi.org/10.5539/enrr.v5n2p165

Yang, L. (2013). A study on the influence of Three Gorges Project to the Dongting Lake wetland landscape pattern and its ecological health (in Chinese). Hunan Normal University, P53.

Yearbook of Hunan Province. (2011). Retrieved from http://www.hntj.gov.cn/

Zhao, M., Cong, P., Barter, M., Fox, A. D., \& Cao, L. (2012). The changing abundance and distribution of Greater White-fronted Geese Anseralbifrons in the Yangtze River floodplain: impacts of recent hydrological changes. Bird Conservation International, 22(2), 135-143. http://dx.doi.org/10.1017/S0959270911000542

\section{Notes}

Note 1. Water storage affects the state of the lake with three different regimes for its SESs, i.e. abundant water (enough water for all uses), seasonal low water (users receive water under a specific scheme) and extreme drought (water is available only for priority schemes) (Ostrom, 1990). It is important in resilience management not to maximise the supply of any resources but to maintain them in a desirable configuration (Walker et al., 2002). Dongting is a seasonally influenced lake. There is abundant water in wet seasons and shortages during dry seasons. In this sense, the desirable state of water storage advocated in this study is "enough for uses". Chenglingji hydrometric station is located in ED. When the water level is $33.5 \mathrm{~m}$ at the station $(1.5 \mathrm{~m}$ higher than the warning water level), flood occurs in the lake region with about 16.76 billion $\mathrm{m}^{3}$ of water storage (Deng et al., 2014). On the other hand, according to the reports, the lowest average water level of the lake was $23 \mathrm{~m}$ (Chenglingji station) in the past decades, below which serious impacts occur including suspension of shipping and fishing (Xinhua Net, 2009). Nanzui and Xiaohezui hydrometric stations are located at the joint point between SD and WD. When the water level monitored in Nanzui and Xiaohezui is about $29.5 \mathrm{~m}$ serious drought happens to SD and WD. The floods warning level is $34 \mathrm{~m}$. Thus, the lower threshold for water level is defined as $23 \mathrm{~m}$ at which the water storage is about 1.33 billion $\mathrm{m}^{3}$ (Xinhua Net, 2009) for ED and $29.5 \mathrm{~m}$ for SD and WD (Wetlands China, 2011). The resilience scale for the lake water storage can be divided into three - between $23 \mathrm{~m}$ 
and $32 \mathrm{~m}$ for $\mathrm{ED}, 29.5 \mathrm{~m}$ for SD and $34 \mathrm{~m}$ for $\mathrm{WD}$.

Note 2. According to the experts, the coverage of emergent macrophytes has to be at least $40-60 \%$ to support the livelihood of water birds in the lake. We set $50 \%$ and $80 \%$ as the thresholds for the low and high levels of resilience of the indicator $I_{3}$.

Note 3. For key resources, the experts suggest that the ratio between regeneration rate and rate of loss should be at least 0.9 to ensure the biodiversity of the lake, i.e. a rate of loss of less than 0.1 . The medium level of resilience for key resources ranges between 0.1 and 0.4 and between 0.4 and 0.7 for low resilience. When the rate of loss is more than 0.4 it is very hard to maintain or recover biodiversity.

Note 4. As thresholds for the urban-rural gaps (Kuijs \& Wang, 2006), we use 3 to 2.5, 2.5 to 2, and 2 to 1.5 , where the systems' resilience is low, medium, and high, respectively. A smaller gap means that the people from rural areas (the lakeshore areas in our case are classified as the rural areas) have relative high ability to generate income when there is loss of economic values due to changes in natural resources.

\section{Appendix 1. Calculation of Weights}

With the set of indicators for the systems' abilities defined as $I_{a}=\left\{I_{1}, I_{2}, \ldots, I_{m}\right\}$, where $m=18$ and the set of all policy indicators defined as $P_{b}=\left\{P_{1}, P_{2}, \ldots, P_{k}\right\}$, where $k=19$, the combined indicators set is presented as:

$$
C=\left\{\left(I_{1}, P_{1}\right),\left(I_{2}, P_{2}\right), \ldots,\left(I_{m}, P_{k}\right)\right\},(m=1,2, \ldots, 18 ; k=1,2, \ldots, 19)
$$

where $\left(I_{m}, P_{k}\right)$ refers to the corresponding combination of $I$ and $P$ indicators for the given subsystem. For instance, there are: one indicator for the systems' absorption ability (i.e. $I_{4}$ - regeneration rate of resources) and two policy indicators (i.e. $P_{2}$ - wetlands restoration plans and $P_{3}$ - protection plans for the resources in the lake) for the subsystem RU4 (quantity of units). Then the combined indicators set for RU4 is $\left[I_{4},\left(P_{2}, P_{3}\right)\right]$. $\left(I_{n_{a}}, P_{n_{b}}\right)$.

More than one indicator and policy option however are used for some subsystems making these repeated indicators and subsystems (in bold on Figure 2) relatively more important for the resilience of the SESs - in bold black for the systems' self-organising abilities and in bold yellow for the policy adaptation options. The relationships between all system abilities and policies generate 28 different combinations (see Table 5).

If a subsystem is described as $S_{n}$ and the weight assigned to it is $\omega_{S_{n}}$, then $\omega_{S_{n}}=\frac{t_{S_{n}}}{n}\left(\omega_{S_{n}} \geq 0, \sum_{n} \omega_{S_{n}}=1\right)$, where $t_{S_{n}}$ is the number of times $S_{n}$ appears in Table 5 and $n$ is the number of combinations, namely 28. For example, RS1.1 appears twice, its weight is then 1/14 while the weight of RS1.2 is $1 / 28$ as it appears once. The equal weights for the combined set $C$ are given by:

$$
\omega_{\mathrm{C}}=\frac{\omega_{\mathrm{S}}}{\mathrm{N}_{\mathrm{I}}+\mathrm{N}_{P}}, \omega_{\mathrm{C}} \geq 0, \sum_{\mathrm{n}} \omega_{\mathrm{C}}=1
$$

where $N_{I}$ and $N_{P}$ denote the number of systems' ability and policy indicators for $S$, which appear in Table 5 . For example, the combined indicators set for RS1.1 is $\left[\left(I_{l}, I_{2}\right), P_{l}\right]$ (see Table 5). As $P_{l}$ appears twice, it is a relatively important indicator, $N_{I}$ and $N_{P}$ are both 2 in this case (i.e. $\mathrm{N}_{I}+\mathrm{N}_{P}=4$ ). The weight for $I_{I}$ and $I_{2}$ is then 0.0179 , i.e. (1/14)/4. As $C$ is composed of $I_{m}$ and $P_{k}$, its weights need to be equally distributed. The weights for $I_{m}$ and $P_{k}$ are given as:

$$
\begin{gathered}
\omega_{I}=\omega_{C}\left\{I_{m}\right\} ; \omega_{P}=\omega_{C}\left\{P_{k}\right\}, \\
\omega_{I}, \omega_{P} \geq 0, \quad \sum_{I=1}^{m} \sum_{P=1}^{k} \omega_{I} \omega_{P}=1
\end{gathered}
$$

In the above example, the weights of $I_{1}$ and $I_{2}$ are distributed to 0.0179 while $P_{1}$ is 0.0357 for the case of RS1.1. However, $P_{l}$ appears as the response not only for RS1.1 but also for RU1 and RU5.2. Its weight thus will be added from the distributed weights from RU1 and RU5.2, reflecting its relative importance in the whole system. The weights for all indicators are listed in Table 5 .

\section{Appendix 2. Aggregation Modelling}

The following steps are used to develop the weighted TOPSIS method applied in this study to assess the 
resilience of the SESs of the lake:

a. Defining the initial indicator set or decision matrix of the SESs:

$$
X=\left(x_{u C}\right)_{u \times j}=\left[\begin{array}{ccc}
x_{11} & \ldots & x_{1 j} \\
\vdots & \vdots & \vdots \\
x_{u 1} & \ldots & x_{u j}
\end{array}\right]
$$

where $x_{u C}$ is the value of the combined indicators set $C$ for the assessed unit $u$. In this case, the assessed units are three with corresponding $j=37$ indicators, i.e. the evaluation matrix $X=\left(x_{u C}\right)_{3 \times 37}$.

b. Establishing the normalisation matrix

As shown in Table 2, the systems' indicators can have two directions: positive (+) and negative (-), and different dimensions. Therefore all indicators need to be normalised into a common dimension. The normalised matrix is given by:

$$
\begin{gathered}
Y=\left[\begin{array}{ccc}
y_{11} & \ldots & y_{1 j} \\
\vdots & \vdots & \vdots \\
y_{u 1} & \ldots & y_{u j}
\end{array}\right], u=1,2,3 ; j=1,2, \ldots, 37 \\
\text { where } y_{u j}=x_{u j} / \sqrt{\sum_{u=1}^{3} x_{u j}^{2}}, 0 \leq \mathrm{y}_{\mathrm{uj}} \leq 1
\end{gathered}
$$

c. Determining negative and positive ideal solutions

The positive ideal solution is the desirable state while negative ideal solution is the undesirable state of the system. They can be defined as $F^{+}$and $F^{-}$respectively and represented as:

$$
\begin{aligned}
& F^{+}=\left(y_{1}^{+}, y_{2}^{+}, \ldots, y_{j}^{+}\right)=\left\{\left(\max _{u} y_{u j} \mid j \in J\right),\left(\min _{u} y_{u j} \mid j \in J^{\prime}\right)\right\} \\
& F^{-}=\left(y_{1}^{-}, y_{2}^{-}, \ldots, y_{j}^{-}\right)=\left\{\left(\min _{u} y_{u j} \mid j \in J\right),\left(\max _{u} y_{u j} \mid j \in J^{\prime}\right)\right\}
\end{aligned}
$$

where $u=1,2,3 ; j=1,2, \ldots, 37, J$ is associated with the positive and $J$ ' with the negative indicator set.

d. Assigning weight vectors for indicators and calculating the distance of each indicator from the ideal solutions

To distinguish the relative importance of the indicators, the established weights (Table 6) are added to calculate the distance of each indicator from the ideal solutions $\left(S_{u}\right)$ by the equations:

$$
S_{u}^{+}=\sqrt{\sum_{j=1}^{37} \omega_{j}\left(y_{u j}-y_{j}^{+}\right)^{2}} ; S_{u}^{-}=\sqrt{\sum_{j=1}^{37} \omega_{j}\left(y_{u j}-y_{j}^{-}\right)^{2}}, u=1,2,3 ; j=1,2, \ldots, 37
$$

e. Determining the relative closeness $\left(C^{*}\right)$ to the ideal solutions for the indicators

The relative closeness describes the performance of the different lake areas. The larger the value of $C^{*}$, the better the performance of the area. The relative closeness of the $u$ th unit can be calculated by:

$$
C_{u}^{*}=S_{u}^{-} /\left(S_{u}^{+}+S_{u}^{-}\right), 0 \leq C_{u}^{*} \leq 1, u=1,2,3
$$

f. Ranking the performance of the lake areas

In the final step, the lake areas can be ranked according to preference using the value of $C^{*}$ in a descending order starting from the best performance.

\section{Copyrights}

Copyright for this article is retained by the author(s), with first publication rights granted to the journal.

This is an open-access article distributed under the terms and conditions of the Creative Commons Attribution license (http://creativecommons.org/licenses/by/3.0/). 